\title{
9 The city, the church, and the 1960s
}

\author{
On secularisation theory and the \\ Swedish translation of Harvey Cox's \\ The Secular City
}

Anton Jansson

In 1994, sociologist of religion José Casanova wrote in the introduction to his influential book Public Religions in the Modern World that a paradigm shift had occurred in his field. His colleagues had abandoned an earlier paradigm "with the same uncritical haste with which they previously embraced it." "What he had in mind was the theory of secularisation: that is, the notion that with modernisation, religion would disappear from the public sphere, if not altogether. The theory was now, he claimed, something of a myth in the eyes of many of his colleagues, rather than the accepted knowledge it used to be.

However, it is reasonable to claim that secularisation is, or above all was, a form of knowledge in the sense of being a well-defined and well-founded conception concerning a certain condition, in this case the fate of religion in modern societies. ${ }^{2}$ With its paradigmatic status, this was knowledge that, in the words of James Secord, was "taken-for-granted", not only in a narrow academic field but for wider groups of people, also outside scholarly circles. ${ }^{3}$

Secularisation theory has a long and multi-faceted history, introduced very briefly in the following, but seemed to enjoy its heyday during the postwar era. Sociologist of religion Hans Joas has claimed:

[W]ith particular self-assurance from the 1960s onwards, those who assumed that secularization was a virtually inevitable outcome of modernization enjoyed hegemonic status in every debate on religion and the future of modern society, whether in philosophy, the humanities and social sciences, or intellectual life in general. ${ }^{4}$

In this chapter, I aim to present and discuss secularisation theory as a timespecific form of knowledge in Sweden. And I do so by focusing on one of the most famous (and infamous) books of the 1960s addressing secularisation, namely The Secular City, by American theologian Harvey Cox, first published in 1965. However, I do not delve deeply into the contents of the book but rather look at its circulation in the Swedish public. ${ }^{5}$ Cox's book was translated into Swedish already in 1966 as Har Gud skapat tätorten?, came out in a further edition in 1967 , and was accompanied by a study material. I put this publication 


\section{Anton Jansson}

in its Swedish context and analyse its initial reception and further circulation in the Christian and mainstream public. In doing so, this chapter focuses on the translation and adaptation of an internationally renowned work into a new national context and how it was remoulded in the process. ${ }^{6}$ The main focus is thus on the circulation of a specific work by a specific author, but by focusing on this book, I also hope to say something broader concerning the articulation and circulation of secularisation theory. Apart from this, this chapter discusses the relationship between religion and knowledge, specifically the role of churches and the entanglement of knowledge with ethical encouragements.

The chapter follows in four parts. I start out with a general brief introduction of secularisation theory, including the Swedish context in relation to this. I then briefly introduce Harvey Cox and his book before turning to its circulation in the Swedish public. First, I present the introduction and initial reception of Cox in Sweden. Here, I emphasise two contextual aspects - urbanisation and discussions about the church - which played an important role both for the publication of the book and for how the book was perceived in reviews and analyses in cultural journals and daily newspapers. In the following part, I present the study material that accompanied the book and discuss how the book was coupled with ethical and political encouragements. In addition to this, I show how Cox became a general point of reference in scholarly presentations of secularisation theory. In a concluding discussion, I pull the threads together and discuss secularisation theory and the history of knowledge in somewhat more detail.

\section{Looking back on secularisation}

In 21st-century discussions on the fate of religion in contemporary society, a specific narrative thrives: religion has "returned" or has "new visibility"; we may today even live in a "post-secular" society. ${ }^{7}$ This is often accompanied by a critique against an earlier simplistic secularisation theory, according to which there was a necessary and universal link between modernisation and the disappearance of religion. Generally, critics of the secularisation theory do not deny that there has been a religious transformation during the modern era but doubt the necessity and universality, as well as the progressive or even teleological implications, of the secularisation theory, which they claim have been dominant for much of the 20 th century. ${ }^{8}$

The concept of secularisation - originating in ecclesiastical law where it meant that something was transferred from an ecclesiastical (churchly) to a non-ecclesiastical (secular, worldly) domain - was established as a culturalhistorical concept in most European languages in the early 20th century. ${ }^{9}$ However, the idea that human progress would disqualify, marginalise, and even wipe out religion has a longer history. Enlightenment philosopher Voltaire once predicted that the death of Christianity would arrive within fifty years, and in his famous outline of human progress, his younger colleague Condorcet envisioned a society where human beings recognised "no other master but their reason", which meant that priests would exist only in history books. ${ }^{10}$ This 
notion grew stronger among intellectuals during the 19th century and gained more scholarly credibility with the establishment of sociology. Auguste Comte imagined that the theological and metaphysical stages in human progress would be succeeded by a positivistic era, and Max Weber's foundational notion of the disenchantment of the modern world could be considered a variant of secularisation theory. ${ }^{11}$

Hans Joas is not alone in having identified the 1960s and 1970s as the period when secularisation theory was at its peak. ${ }^{12}$ During these decades, there was much scholarly output offering theoretical substance to the idea of secularisation. Thomas Luckmann in The Invisible Religion famously formulated a secularisation theory positing that the traditional religious institutions were doomed and that religion in modern society would increasingly be found in the private sphere. ${ }^{13}$ His colleague Peter Berger wrote in The Sacred Canopy that secularisation was a "global phenomenon of modern societies". ${ }^{14}$ Similarly, Bryan Wilson claimed that while societies differed in how secularisation occurred, secularisation could be taken "simply as a fact". ${ }^{15}$ Some of these scholars have later recanted. Berger - whose prediction in the New York Times in 1968 that religion would be virtually gone by the turn of the millennium is often quoted as a sign of the self-assurance of secularisation theorists - in 1999 instead published a book entitled The Desecularization of the World. ${ }^{16}$

Sweden, during this period famous for developing a modernist self-image and identity, is no exception to the rule that secularisation theory constituted an important part of the interpretation of where society was heading. In Swedish society, this had, for instance, been prepared in the 1950s by influential political scientist and newspaper publisher Herbert Tingsten. Tingsten is noted for at an early stage presenting a theory on the end of ideologies, accompanied by propagating for the case that religion was dying out as well. Thanks to the rationalisation of modern societies since the Enlightenment, Tingsten held, people no longer believed in religious truths, and what was left was a toothless church with a non-substantial message that was on its way to becoming irrelevant. ${ }^{17}$ Others agreed, whether or not they shared Tingsten's culturally radical values: the priest Egon Åhman, for instance, in the mid-1960s published an extensive and much noted characterisation of secularisation from historical, sociological, and theological perspectives, and here as well, it seemed selfevident that society was steadily bound to a process of secularisation. ${ }^{18}$

It should be pointed out that the fact that secularisation theory was widespread is not the same as there being a secular society. The secular character of postwar Sweden should not be exaggerated, and the 1960s did present a strong Christian public sphere and movement in Sweden. ${ }^{19}$ This was no monolithic entity: theologically, institutionally, and politically, Christianity spanned a wide field, inside the Lutheran state church and outside. There were older free churches, such as the Mission Covenant Church, Methodists, and Baptists with roots in the 19th-century popular movements, and newer ones, such as the Pentecostal movement. These all had to react to and position themselves in relation to secularisation and did so with varying degrees of zeal. 
In 1964, a new political party was established. The Swedish Christian Democrats (KDS, Kristen demokratisk samling, today Kristdemokraterna), mainly an organ of the Pentecostal movement and not supported by the older free churches, was founded over a "concern about the far-reaching secularisation of society." 20 The igniting sparks consisted of a reaction to the substitution of confessional Christianity studies (Kristendomskunskap) for neutral religious studies (Religionskunskap) in upper secondary schools and the perceived loss of public morality, primarily represented by the controversial 1964 movie $491 .^{21}$ KDS wanted to counter secularisation, which the party at the time frequently conceptualised as the de-Christianisation (avkristning) of Sweden.

Secularisation could perhaps be countered, but the epistemological credibility of the secularisation theory was rarely challenged. In a way, secularisation theory was accepted and even bolstered by parts of the Christian establishment. While KDS was perceived as a "battling party" 22 against secularisation, in other corners of the Christian public sphere, it was not self-evident that secularisation should be countered. Both in Sweden and internationally, there were tendencies to rather accommodate ideas concerning secularisation and the demise of religion within Christianity and Christian thought. The so-called "Death of God theology" emerged in the early 1960s. This was heterogeneous but included various ways of theologically responding to living in a society where God was perceived as dead; in some cases, it even meant affirming the death of God. ${ }^{23}$ A related movement was what has been termed secularisation theology or secular theology, which still advocated the existence of God but embraced secularisation as welcome to or even grounded in the Christian tradition. In this context, internationally and in Sweden, Harvey Cox's The Secular City became one of the most notable and circulated works. Before presenting its fates in the Swedish public, I briefly introduce Cox and the main arguments in his book.

\section{Harvey Cox and The Secular City}

At the beginning of 1965, Harvey Cox was an anonymous Baptist minister and assistant professor who had finished his dissertation at Harvard in $1963 .{ }^{24}$ A year later, however, he was one of the most famous theologians in the world, owing to the unexpected success of a paperback book he published, which landed on the bestseller list in the United States. The book was eventually translated into fourteen languages and sold nearly a million copies worldwide. Leading Christians all around the globe read it, including Pope Paul VI, who in an audience with Cox told him that while he did not agree with all of it, he had read the book with great interest. ${ }^{25}$

The book was called The Secular City: Secularization and Urbanization in Theological Perspective and was based on themes from Cox's doctoral dissertation, which was on religion and technology. ${ }^{26}$ In the book, he mainly linked secularisation theory to discussions about urbanisation, for instance, referring to the famous urban theoretician Lewis Mumford. Cox himself claimed that he was astonished by the success of the book, which he originally drafted to serve 
a specific purpose, namely serving as a study material for a series of conferences held by the National Student Christian Federation. ${ }^{27}$ However, writing about secularisation with engaged laypeople in mind, rather than colleagues in theological seminars, turned out to be a recipe for success. Cox later called the book a pamphlet, written not in a scholarly manner but in a sweeping, stylistically non-academic way, making it accessible to a wider public. ${ }^{28}$ The pamphlet character and accessibility certainly contributed to the success of the book. A decisive element was also how Cox linked theology to many of the hottest social issues of the day. Apart from urbanisation and modern city life, the book also thematised topics such as sex and sexuality, work life and the modern organisation, as well as education.

Cox later claimed that "the city" in the book was a kind of metaphor for modern life in a secular society, but the city and urbanisation were certainly very tangibly presented in a highly modernist or even futuristic way. He speaks about the "technopolis", about "cybernation" (a combination of cybernetics and automation), and what he refers to as an accompanying urban "new cultural style". ${ }^{29}$ A defining characteristic of the city or the technopolis is that it is secular. In what can be termed a stadial interpretation of history, Cox presents the city as a form of third and final stage in a historical development going from the tribe to the town and ending up in the technopolis, the secular city. This is a form of secularisation narrative in that it presents how secularity is the inevitable outcome of modernity. For Cox, secularisation seems to be an entirely self-evident piece of knowledge, something that becomes clear already in the introduction to the book. ${ }^{30}$ That religious events and movements are still noticeable in the public space should not be seen as too significant; they are "no real threat to the secularization process" as religion and metaphysics "are disappearing forever". ${ }^{31}$ Secularisation is totally triumphant and, as he says later in the book, "almost certainly irreversible". 32

Cox not only presented his taken-for-granted view of secularisation; what created his fame (and infamy) was how he embraced it and his positive theological appropriation of secularisation. Here, he was influenced by German theologians such as Friedrich Gogarten, who argued that secularisation in a sense was an emanation of Christianity into the world, and Dietrich Bonhoeffer, who formulated the need for a "religionless" Christianity. ${ }^{33}$ Cox claims that secularisation is something positive: "it is basically a liberating development", a deliverance of man from religious and metaphysical control and oppression. ${ }^{34}$ It emancipates the human being and lets him or her become the master of the world, a partner with God, who is free to do godly works in the world. Cox cites Bonhoeffer in saying that secularisation means "man's coming of age". 35 This positive interpretation was not restricted to secularisation but is similar regarding urbanisation. The anonymity and rootlessness of the secular city, Cox claims, must be interpreted as something positive, as this could mean a liberation from burdensome expectations of town life and could serve as an antidote to ossification within the Christian community. In biblical terms, it is a deliverance from the Law, and from Baal, from stale traditions and false idols. ${ }^{36}$ 
As mentioned earlier, the book was a commercial success, and its brashness made it a topic of debate. As soon as 1966, an edited volume dedicated to this debate was published, and the same year, there were already six translations underway. ${ }^{37}$ One of them was into Swedish, the only Scandinavian language into which the book was translated. And in Sweden it resonated well with certain developments in church and society.

\section{Har Gud skapat tätorten? Publication and initial reception in Sweden}

Swedish Christianity during the 1960s was generally attentive to what was going on in American Christian life and theology, so it was no surprise that word of Cox's success would reach the country. When Torsten Kälvemark, later a well-known author and top civil servant, reviewed the just published Swedish translation in late 1966, he said that this book was already something that had to be mentioned if you wanted to show that you were a jour with the theological debate. ${ }^{38}$ Kälvemark points out that Cox was introduced to the Swedish public by Kerstin Anér earlier that year. While Kälvemark missed that Cox's sensational book was discussed in Kristet Forum, the journal of the free church movement student association, already in 1965, he had a point in that Anér was a key introducer. ${ }^{39}$

Anér wrote about The Secular City in the Christian cultural journal Var Lösen but presented it for a wider public as well in the spring of $1966 .{ }^{40}$ Anér, who later became a top politician for the liberal People's Party, was at the time not only a writer but also a radio producer on the national public radio. In a broadcast of the programme Tidsspegel, which was an important programme for three decades (1947-1976) and where current debates and hot topics were presented, she discussed Cox and linked him to a well-visited exhibition about urbanity, Hej Stad!, at the newly opened architectural museum in Stockholm. ${ }^{41}$ And when the Swedish translation of the book was published towards the end of 1966, Anér was included on the back cover with a quote from her earlier review, stating that Cox is no "academic theologian but a man who wants things done, Kennedy style." 42

When Cox's work was published in Sweden, the title was not translated literally. In Swedish, the book was called Har Gud skapat tätorten? Kristen tro och sekulariserat stadssamhälle [Has God created the locality? Christian faith and secularised urban society]. The word tätort, officially translated as "locality" but hard to translate literally, was topical. In 1960, the term was officially adopted jointly by the governments of the Nordic countries and given the definition that it "consists of a group of buildings normally no more than 200 metres apart from each other and must fulfil a minimum criterion of having at least 200 inhabitants." 43 It was used to statistically distinguish between urban and non-urban areas, and in this way, it was reasonable to use it to denote something urban. However, a locality could be very small and, in that sense, very different from the technopoleis Cox was writing about. This was also pointed out by a few of the Swedish reviewers. ${ }^{44}$ 
The publication in Swedish of a controversial or at least debated foreign work of theology was not without precedent. In 1964, the English bishop John Robinson's Honest to God - a work that has been linked to the Death of Godmovement ${ }^{45}$ - was published in Swedish as Gud är annorlunda [God is different] by the publishing house of the Swedish Mission Covenant Church. ${ }^{46}$ In a sense, Har Gud skapat tätorten? was the logical follow-up to the publication of Robinson's work but was instead issued by a publishing house linked to the state church. Svenska Kyrkans Diakonistyrelse, short Diakonistyrelsen, founded in 1910 had many tasks within the church, including organising social work, local parish work, publicity, and education for laypeople. ${ }^{47}$ Part of the latter mission was the publishing house SKDB, later Verbum, which published Har Gud skapat tätorten?

Diakonistyrelsen also issued a weekly newspaper, Var Kyrka, where the publishing house regularly presented its newest publications. In late 1966, Har Gud skapat tätorten? was here introduced as the highlight of the season's publications and presented as the greatest attempt in a long time to interpret the contemporary world in light of the Bible. ${ }^{48}$ There were also ads for the book posted in the major daily newspapers, and the caption here was that the book was widely debated in the United States and Europe, and it was also pointed out that the author looked upon secularisation not as a threat but as a possibility. ${ }^{49}$

The book was reviewed, discussed, and/or analysed in the major Christian cultural journals, both the more liberally inclined, such as Varr Lösen, Kristet Forum, and Arsbok för Kristen Humanism, and the more conservative Svensk Pastoraltidskrift and Nya Väktaren. ${ }^{50}$ The review in the latter stands out in its assessment of the work as "heretical" (kättersk) and in warning the readers. ${ }^{51}$ Otherwise, there are some general themes in its initial reception - themes that were also raised when the book was addressed in the large daily newspapers Aftonbladet, Expressen, and Göteborgs-Tidningen: Cox's book was seen as an inspiring or challenging work, especially for the modern church, but overly optimistic. Furthermore, the discussions concerning it revolved around the city.

To begin with the latter point, that Cox's book was not only about secularisation or modernity in general but about the city seems to have hit a nerve in mid-1960s Sweden. Also 1966, the year of Har Gud skapat tätorten?, has been referred to by philosopher Sven-Olov Wallenstein specifically as the year of "thinking the city" in a retrospective discussion on the previously mentioned exhibition Hej Stad! ${ }^{52}$ And not only in 1966 alone but in the mid-1960s Sweden saw a peak in public debates about urban life. In 1965, the so-called Million Programme was launched. This was a national initiative to erect one million houses and apartments in ten years, which was criticised already at the time; above all, the large apartment blocks in newly designed suburbs were seen as a "newly-built slum". ${ }^{33}$ Another necessary form of modernisation of cities, albeit deplored by many, consisted of redevelopments where older houses were torn down to make way for more modern city centres. The most ambitious and most contested of these was the redevelopment of Norrmalm in central Stockholm. This went on from the 1940s into the 1970s but was in its most intensive 
phase in the 1960s. ${ }^{54}$ The landmark edifices of the project, the five tall "Hötorget skyscrapers" were finished in 1966, and they made it to the cover of the Har Gud skapat tätorten? In the picture depicting a neon-lit Stockholm by night, the skyscrapers are symbolically foregrounded by the nearby Klara Church, which has one of the tallest church towers in Sweden.

Modern cities, urban life, and the perceived downsides of these were widely discussed also by Christian actors. Notable is that in the first party platform of KDS, no fewer than three of its twelve points addressed the city in one way or another. It speaks about the "unfortunate" migration to towns and the "maladjusted and lost" inhabitants of the large cities. ${ }^{55}$ An interesting fact here is that the Swedish Christian Democrats Party modelled its platform on the Norwegian party Kristelig Folkeparti, founded in 1933, with the exception that the three points on the city did not have counterparts in the previously founded Norwegian party. ${ }^{56}$ The utter topicality of the city in Swedish debates in 1966 is probably one of the reasons why Cox's book was discussed and translated (for instance, it was not translated into the other Scandinavian languages), and as mentioned earlier, it was also a main theme in the reception.

The Hötorget skyscrapers illustrated the article about Cox (with the headline Halleluja Stad!) by author and priest Rune Pär Olofsson in Expressen, and a tower crane was pictured in a long article in Göteborgs-Tidningen written by Bernt Eklundh, at the time cultural editor of the paper. He very tangibly links Har Gud skapat tätorten? to the development of Gothenburg, as he writes about moving to the countryside northeast of the city only for this area to be incorporated into the city when the authorities created the new suburb of Angered, the largest Million Programme area in the city. While Eklundh denies that there is a strict dichotomy between urban and rural lifestyles, his main critique of Cox's book is that the author has nothing to say about the noise, stench, and overcrowding of the modern city. ${ }^{57}$ That Cox has too little to say about the downside of the city is a critique presented by both the more positive and the more negative reviewers. In Kerstin Anér's generally welcoming review in Var Lösen, she ends by asking whether Cox was not too positive about the city in light of what is known about biocides and noise. ${ }^{58}$ Religious scholar Eric J. Sharpe later reviewed the Swedish translation more negatively in a longer article in Var Lösen, and one of his points was that Cox was wrong about the city, which in reality is full of loneliness, meaninglessness, addiction, and suicide. ${ }^{59}$ Ragnar Oldberg in Kristet Forum has another version of this, claiming that it is remarkable how Cox hides facts by not acknowledging warnings from the World Health Organization concerning the health hazards of modern cities. ${ }^{60}$

In the Swedish reception, Harvey Cox thus almost mainly appeared as a (partly flawed) interpreter of the city, and the point that the city could almost be a metaphor for modern secularity was not appreciated, as his discussions about the city were taken at face value. That a book about urbanisation spurred discussions about city life is naturally self-evident in one sense. But while the contents of books are fixed, they may come to mean different things in their circulation, or at least be given different accents. ${ }^{61}$ In the case of Har Gud skapat 
Tätorten?, it is notable that the Swedish discussion differed from the international. The part that was most widely debated and most quoted in general, according to Cox himself, was the chapter on sex. ${ }^{62}$ In Sweden, however, this theme was mostly mentioned in passing, if at all. The reason for this is probably that Sweden had already experienced a very lively debate on sex and sexuality during the first half of the 1960s, when there was a breakthrough of sexual liberalism. However, according to its main historiographer Lena Lennerhed, this debate ended quite suddenly in 1965 and was not that topical in 1966 and 1967. This had also been somewhat more radical than Cox, who mainly criticised Playboy and propagated for a more pragmatic view on pre-marital sex, which probably meant that there was not enough to awaken the Swedish discussion - not even in Christian circles, which had not been untouched by the earlier debate. ${ }^{63}$ The chapters on work life and universities were also hardly picked up in the Swedish reception.

Another aspect of the book that was picked up and related to Swedish conditions, however, was the challenges facing the church in modern society. If one important contextual aspect of the 1960s was urbanisation, another was discussions about the relationship between, on the one hand, the church and, on the other, the state and society. Since the adoption of a new law on the freedom of religion in 1951, which finally allowed Swedish citizens to leave the state church without having to belong to another officially recognised denomination, there had been calls for further reform of the Church of Sweden, above all for a separation of church and state. From 1958 to 1968, a large government study was carried out on the future of the state-church relationship, suggesting various solutions to the issue. While the question was eventually tabled in 1973 and not resolved until 2000, when the Church of Sweden ceased to be a state church, it was highly topical throughout the 1960s. ${ }^{64}$ And the issue of the relationship between church and state was not only formal or legal, it also had to do with the relationship of the church with politics, society, or "the world" in general.

Reviewers often mentioned how Cox insisted that the church had to avoid being dogmatic and introvert. In the first presentation of Cox's book, by Olle Engström in the free church journal Kristet Forum, a longer description of The Secular City is included in an article entitled "Radical critique of the church" (Radikal kyrkokritik). ${ }^{65}$ In the older free churches, which were generally more liberal than the younger Pentecostal movement, there was a positive reception of Cox's call for church reform and the embrace of secularisation. In meetings in both the free church student movement and for free church theologians around the New Year 1966/67, Cox's book was a central topic and discussed in positive terms. A message then picked up was how going out in the world should be prioritised over an inward orientation within the churches. ${ }^{66}$

In Expressen, the priest Rune Pär Olofsson focused on how Har Gud skapat tätorten? was an "explosive device" against a state church reluctant to take criticism. ${ }^{67}$ Regarding the state church, Cox's book also became more topical later in 1967, partly linked to the election of a new archbishop of Sweden. One of 
the (unsuccessful) candidates had been Krister Stendahl, who was a professor of theology at Harvard. He had discussed the sensational book by his colleague Cox in Var lösen already before it was published in Swedish, claiming that it was an "utterly emancipatory" work. ${ }^{68}$ In an interview in Expressen a few months after the election, which spurred further debate, Stendahl advocated a separation between church and state, and while he did not here mention Cox by name, other actors claimed that he had influenced Stendahl's unexpected position regarding the church. Another priest, Ingemar Ström, pointed this out in an attack on Stendahl. And the Swedish publisher of the book used this opportunity: ten days after the interview with Stendahl, it placed an ad in Expressen, saying that in order to understand Stendahl's position and the ensuing debate, one must read Har Gud skapat tätorten? and even included a cut-out coupon for ordering the book. ${ }^{69}$

So, Cox relatively quickly became a kind of general point of reference and stayed this way into the 1970s. He was often mentioned in passing as an example of internal criticism against the church and secularisation. ${ }^{70}$ In other words, Har Gud skapat tätorten? was not quickly forgotten. It did come out in a second edition in 1967, something that the translation of John Robinson's Honest to God did not achieve, and, as we shall see, there was some further circulation of Cox's ideas.

\section{Further circulation: study material and scholarly works}

As mentioned earlier, almost a trope in the reception of The Secular City in Sweden, both in its English and Swedish incarnations, was that it was inspiring and challenging but too optimistic. This was the case regardless of whether the main assessment was critical or positive. Those who praised it admitted that it was perhaps too positive. In a generally affirmative evaluation, Hansson in Kristet Forum talked about Cox's "tiring self-confidence", and Anér said he was "overly optimistic". ${ }^{71}$ Those who were more sceptical towards Cox still admitted that he raised important issues. Kälvemark, for instance, argued that Cox in his optimism was oblivious to the realities of the city but that there were inspiring and thought-provoking aspects of the book. ${ }^{72}$ This comes close to how many reviewers claimed that Cox's way of posing questions was important and that the questions rather than the answers represented the real value of the book. In this lay an assessment that the present condition of the secularised modern urban life challenged Christians to respond to societal issues in new ways. In the words of Olle Engström, it was "time to leave the hammocks". ${ }^{73}$

One version of this trope came from Pastor David Holm, who worked for the church with adolescents. In Arsbok för Kristen Humanism, Holm writes that Cox admittedly may be "too optimistic" and "over-simplistic" but that he was "receptive to the most important questions of our time." 74 And this rhymed well with Holm's further work in circulating the book, as Holm was the one to write a study material published by SKDB in 1967, entitled Tro i teknopol: studieplan till Harvey Cox Har Gud skapat tätorten? (Faith in technopolis: Study plan 
for Harvey Cox Har Gud skapat tätorten?). On the back cover of the booklet, it is stated that it "presents and complements the subject, so that it becomes easier to absorb Cox's often very unconventional lines of thoughts." 75 In particular, Holm in the short introduction to the study material explains that it may be difficult to understand how a Christian theologian could praise what is often condemned in the churches. ${ }^{76}$ At the beginning of the study plan, there is a focus on acknowledging that Cox's use of the concepts of religion and secularisation is unconventional.

Holm then follows Cox's book quite closely. With one exception, each chapter of Har Gud skapat tätorten? gets one chapter in the study plan, and each chapter is envisaged as one meeting with a study group. ${ }^{77}$ In most cases, Holm's chapters consist of a few pages of condensed and introductory formulations of Cox's ideas. In some cases, Holm explains how Cox's points are typically American; for instance, he presents what the Ivy League universities are and how the relationship between state, churches, and universities differs between the United States and Sweden. In a few instances, he also exemplifies with a Swedish equivalent to what Cox is discussing. ${ }^{78}$

Apart from this, Holm adds a couple of things in the study material. First, there is a selection of "words to explain", at least implicitly addressed to the leader of the study group. Second, and key here, is that each chapter ends with between four and seven questions for the group to discuss. These are both aimed at providing a better understanding of the book, the secularisation process, and contemporary society and at encouraging ethical engagement in society, various ways of asking what a Christian and the church should do. Some typical examples include: "Discuss secularisation as the necessary condition of 1) scientific research, 2) the development of under-developed countries"; "How could a constructive moral relativism help ethically confused contemporary human beings?"; "What should be the consequences of Cox's broader view of deaconry for the church's diaconic function?"79 In this sense, the ethical encouragements undoubtedly already existing in Cox's work are strengthened in the study material; there is a combination of trying to acquire and absorb the knowledge about secularisation and modern urban life with a discussion of what is to be done by the modern Christian in order to create a better society.

Harvey Cox did not have an immediate presence in Swedish academic fora. A couple of the articles in the Christian journals discussed earlier had a more scholarly depth, but neither The Secular City nor Har Gud skapat tätorten? were reviewed in the academic theological journal Svensk teologisk kvartalskrift. ${ }^{80} \mathrm{With}$ time, however, he did make an impact and became a common point of reference. The Secular City played a role not least in introductory works. In the 1971 book Att tolka Gud idag by theology professor Per Erik Persson, which was an introduction to contemporary theology widely used in university courses, Cox was one of the theologians referred to the most, and his positions on secularisation and the conception of God were extensively presented as being at the forefront of modern theology. ${ }^{81}$ 
Moreover, the 1960s were a time for sociology of religion, not only internationally but also in Sweden. The most prominent sociologist of religion was Berndt Gustafsson, who was a church historian but in 1962 founded a new institute for sociology of religion (Religionssociologiska institutet). ${ }^{82}$ Gustafsson and his colleagues at the institute published extensively about religion in Sweden during the 1960s and 1970s, frequently empirical studies of the religious habits of Swedes. Gustafsson was not primarily a secularisation theorist; however, with time he developed his accounts of secularisation. And here as well, Cox's The Secular City was one of the (not so many) examples of secularisation theory, which notably did not include some of the more famous sociologists, such as Berger and Luckman. ${ }^{83}$ This further use of Cox's work means that his version of the secularisation theory was known to students and other readers interested in theology and the sociology of religion well into the 1970s.

Cox's later activities in the so-called Christian-Marxist dialogue also enabled him to enjoy continued relevance in large parts of Swedish Christianity, which turned leftwards around 1968, and a couple of his 1970s books were translated. ${ }^{84}$ This also meant a subtle shift in how his works were interpreted. This can be seen in a 1968 book by two younger scholars at the Uppsala University Faculty of Theology, which presents contemporary debates on ethics and worldviews. Here, Cox is the only secularisation theorist mentioned by name, and The Secular City is widely quoted. In relation to this, however, they mention that this work contains political preaching. ${ }^{85}$ This is a further step in the ethical encouragement aspect discussed previously, highlighting that secularisation implies not only a social but also a political engagement in the world.

\section{Concluding discussion}

I would like to conclude this chapter by more explicitly pointing out a few points relating to the field of the history of knowledge. First, the book The Secular City/Har Gud skapat tätorten? has been analysed as a form of knowledge object in transit; above all, its adaptation into and circulation within the Swedish public has been in focus. Studying geographical migration and translations from one language to another tells us something about the constant transformations and remoulding of knowledge. ${ }^{86}$ This has been pointed out by many historians of knowledge, such as by Johan Östling and David Larsson Heidenblad, when they present their view of what they call societal circulation of knowledge. Another point in their discussion is also relevant to highlight here, and that is how crises or perceived changes in society contribute to spark and form the circulation of knowledge objects within society. ${ }^{87}$ Regarding the book at the centre of this study, it is clear how topical issues such as urbanisation and the future of the church were contextual aspects necessary to produce an interest in translating the book and that these contextual aspects also shaped how Cox's book was perceived in a specific way in Sweden. With time, secularisation theory became more emphasised as Cox was used as a, if not the, main representative in presentations of secularisation theory and secularisation 
theology. The political side of Cox's work also seemed to be more important from 1968 onwards, while the theme of urbanisation was less so.

The point of this chapter, however, does not solely concern the migration of Cox's book in itself. Rather, the book has been of interest as a key articulation of secularisation theory during the 1960s. I believe that the analysis of the circulation of Cox's work in Sweden in this chapter has confirmed what is often presented somewhat sweepingly: that the 1960s were a heyday of secularisation theory and how secularisation was more or less taken for granted and selfevident. Church historian Hugh McLeod has claimed that while there were more systematic scholarly works on secularisation in the 1960 s, the one major work responsible for bringing the secularisation theory to a wider audience was Harvey Cox's The Secular City. ${ }^{88}$ And while, as discussed earlier, the notion of secularisation was not new in Sweden, the introduction of Cox's work, which was frequently presented and referred to throughout the late 1960s and early 1970 s, seems to have accelerated and deepened the circulation of secularisation theory as time-specific knowledge within the Swedish public sphere.

The analysis of circulation may thus be seen on two levels here. First, a specific work may circulate. This includes the initial reception, in the form of traditional reviews, but goes wider to include how a work was later remembered, used, and referred to. ${ }^{89}$ Second, the circulation of a specific work can be seen as a moment or piece of the puzzle in the ongoing formation and circulation of knowledge in society. In this way, books, or specifically certain bits and pieces taken out of books and discussed in public, play an important role in how knowledge circulates and is established within society. This is the case not least for the 1960s and 1970s, when discussions about non-fiction books played a particularly important role in the public dialogue.

In the case of Harvey Cox and his bestseller, there is also a link to the relationship between religion and knowledge more generally. If following the common dichotomy where knowledge is at on one side and faith or belief on the other, religion, religious actors, and arenas could easily be neglected in the historical study of knowledge. But such neglect would possibly mean an insufficient understanding of history. ${ }^{90}$ First, this is because religious propositions in one period regarded as irrelevant or superstitious may have been regarded as accepted knowledge in an earlier era. Second, and more relevant for this study, even in contexts where central theological propositions are disqualified as knowledge per se, religious actors are still potentially important conveyers and circulators of different types of knowledge. Churches must be integrated as important actors in the circulation of knowledge in terms of providing arenas for the dissemination of knowledge through the array of publishing houses, journals, educational organisations, and so on linked to the various denominations. In this way, religious actors could be important with regard to forming knowledge. This is not least true for the period in focus of this volume.

The publication of Harvey Cox in Swedish is one example of this, and the general circulation of secularisation theory represents a larger, more important example. Christian Sweden has often been theologically and politically diverse 
and strongly so during the 1960s, meaning that there were different attitudes towards secularisation. Still, however, a main position during the decade seems to be that the theory of secularisation was accepted, or even taken for granted. The point was thus not so much to epistemologically negate it but rather finding ways of accommodating and understanding what this possibly multifarious theory actually meant. Cox's message that secularisation was a good thing, possibly even something with its roots in Christianity, proved to be one possible way of understanding and claiming secularisation, circulated by religious actors.

What the reception of Cox's work further shows is an interesting link between knowledge and ethics, in the sense that knowledge calls for different types of action and ethical engagements. Secularisation, a specific form of knowledge about the state and direction of religion in modern societies, whether perceived as negative or positive, provided Christianity with certain problems (or opportunities) that had to be addressed. This means a perception where Christians had to stand up to the challenge and develop new forms of social and diaconic engagements, churchly organisations, and missionary work if they wanted to make the world a better place. This was a major theme in the reception of Harvey Cox's The Secular City/Har Gud skapat tätorten? in both Christian and mainstream media and an important thread in the study material accompanying the book. Thus, the circulation of Cox's work has told us something not only about secularisation theory but also about religion, knowledge, and ethics more generally.

\section{Notes}

This chapter presents research funded by the Knut and Alice Wallenberg Foundation

1 José Casanova, Public Religions in the Modern World (Chicago: University of Chicago Press, 1994), 11.

2 Johan Östling, "Vad är kunskapshistoria?” Historisk tidskrift 135, no. 1 (2015): 116.

3 James Secord, "Knowledge in Transit", Isis: A Journal of the History of Science 95, no. 4 (2004): 655.

4 Hans Joas, Faith as an Option: Possible Futures for Christianity (Stanford: Stanford University Press, 2014), 9.

5 David Larsson Heidenblad, "From Content to Circulation: Influential Books and the History of Knowledge", in Circulation of Knowledge: Explorations in the History of Knowledge, eds. Johan Östling et al. (Lund: Nordic Academic Press, 2018).

6 Johan Östling and David Larsson Heidenblad, "Cirkulation - ett kunskapshistoriskt nyckelbegrepp", Historisk tidskrift 137, no. 2 (2017): 283.

7 Michael Hoelzl and Graham Ward, eds., The New Visibility of Religion: Studies in Religion and Cultural Hermeneutics (London: Continuum, 2008); Ola Sigurdson, Det postsekulära tillståndet: Religion, modernitet, politik (Gothenburg: Glänta, 2009); Alister Chapman, John Coffey, and Brad S. Gregory, eds., Seeing Things Their Way: Intellectual History and the Return of Religion (Notre Dame: University of Notre Dame Press, 2009); José Casanova, "Are We Still Secular? Explorations on the Secular and the Post-Secular", in PostSecular Society, eds. Peter Nynäs, Mika Lassander, and Terhi Utriainen (New Brunswick: Transaction Publishers, 2012); Anton Jansson and Hjalmar Falk, "Religion i det svenska idéhistorieämnet: översikt och reflektion”, Lychnos (2017): 74-95; Joel Halldorf, Gud: Återkomsten - hur religionen kom tillbaka och vad den betyder (Örebro: Libris, 2018). 
8 Rodney Stark, “Secularization, R.I.P”, Sociology of Religion 60, no. 3 (1999): 268-269; Joas, Faith as an Option, Ch. 1.

9 Werner Conze, Wolfgang Strätz, and Hermann Zabel, "Säkularisation, Säkularisierung", in Geschichtliche Grundbegriffe: Historisches Lexikon zur politisch-sozialen Sprache in Deutschland. Bd 6, St-Vert, eds. Otto Brunner, Werner Conze, and Reinhart Koselleck (Stuttgart: Klett-Cotta, 1990); Lucian Hölscher, "The Religious and the Secular: Semantic Reconfigurations of the Religious Field in Germany from the Eighteenth to the Twentieth Centuries", in Religion and Secularity: Transformations and Transfers of Religious Discourses in Europe and Asia, eds. Marion Eggert and Lucian Hölscher (Leiden: Brill, 2013).

10 Nicolas de Condorcet, "Sketch for a Historical Picture of the Progress of the Human Mind: Tenth Epoch", Daedalus 133, no. 3 (2004): 69.

11 Apart from conceptual histories, long-term empirical studies on the development of the secularisation theory are rare. For short outlines, see Stark, "Secularization, R.I.P.”; Joas, Faith as an Option.

12 Hugh McLeod, Secularisation in Western Europe, 1848-1914 (Basingstoke: MacMillan, 2000), 2-3; Thomas Großbölting, Losing Heaven: Religion in Germany Since 1945 (New York: Berghahn, 2017), 7; Halldorf, Gud: Aterkomsten, 22.

13 Thomas Luckmann, The Invisible Religion: The Problem of Religion in Modern Society (New York: Macmillan, 1967).

14 Peter L. Berger, The Sacred Canopy: Elements of a Sociological Theory of Religion (New York: Anchor Books, 1969), 108.

15 Bryan R. Wilson, Religion in Secular Society: A Sociological Comment (London: Penguin, 1966), 11.

16 Peter L. Berger, ed., The Desecularization of the World: Resurgent Religion and World Politics (Grand Rapids: Eerdmans, 1999). See also Stark, "Secularization, R.I.P”, 251. Berger's 1968 prediction is mentioned in, inter alia, Joas, Faith as an Option, 14; Jansson and Falk, "Religion i det svenska idéhistorieämnet", 75; Halldorf, Gud: Återkomsten, 21.

17 Johan Lundborg, Ideologiernas och religionens död: En analys av Herbert Tingstens ideologi- och religionskritik (Nora: Nya Doxa, 1991). On religion, see in particular pages 125-146.

$18 \AA$ Ahman wrote this on commission from the state church. The task was to write about how the church should orient itself in a world that was "in a state of secularization". Egon Åhman, Sekulariseringsprocessen och kyrkan: Några orienterande synpunkter (Stockholm: Diakonistyrelsen, 1966), 7.

19 Henrik Berggren, 68 (Stockholm: Max Ström, 2018), 116-141.

20 Göran V. Johansson, Kristen demokrati på svenska: Studier om KDS tillkomst och utveckling 1964-1982 (Malmö: Liber Förlag/Gleerup, 1985), 131. However, the party did not reach the Swedish parliament until 1991.

21 Ibid., 69-140. On the successive changes in religious education, see Karin Kittelmann Flensner, Religious Education in Contemporary Pluralistic Sweden (Gothenburg: Göteborgs universitet, 2015), 30-39.

22 Johansson, Kristen demokrati, 125.

23 Gabriel Vahanian, The Death of God: The Culture of Our Post-Christian Era (New York: G. Braziller, 1961); Thomas J.J. Altizer and William Hamilton, Radical Theology and the Death of God (Indianapolis: Bobbs-Merrill, 1966).

24 George Huntston Williams, Divinings: Religion at Harvard: From Its Origins in New England Ecclesiastical History to the 175th Anniversary of the Harvard Divinity School, 1636-1992, vol. 2, The Augustan Age: Religion in the University, the Foundations of a Learned Ministry and the Development of the Divinity School (Göttingen: Vandenhoeck \& Ruprecht, 2014), 521.

25 Harvey Cox, “The Secular City: Twenty-Five Years Later", in The Secular City: Secularization and Urbanization in Theological Perspective, ed. Harvey Cox (Princeton: Princeton University Press, 2013), liv; Harvey Cox, "Introduction to the New Edition", in The Secular City: Secularization and Urbanization in Theological Perspective, ed. Harvey Cox (Princeton: Princeton University Press, 2013), xi-xiii. 
26 Williams, Divinings, 521.

27 Harvey Cox, "Författarens förord till den reviderade upplagan", in Har Gud skapat tätorten? Kristen tro och sekulariserat stadssamhälle, ed. Harvey Cox (Stockholm: SKDB, 1966), 9-11.

28 Ibid., 10; Cox, "The Secular City", xliii.

29 Harvey Cox, The Secular City: Secularization and Urbanization in Theological Perspective (Princeton: Princeton University Press, 2013), 5-6, 216-217.

30 Ibid., 1-4.

31 Ibid., 3-4.

32 Ibid., 3-4, 25.

33 For a discussion on the influence of German theology on American theology during the postwar period and specifically Gogarten's influence on Cox, see D. Timothy Goering, Friedrich Gogarten (1887-1967): Religionsrebell im Jahrhundert der Weltkriege (Berlin: De Gruyter Oldenbourg, 2017), 368-373.

34 Cox, The Secular City, 2, 21, 25.

35 Ibid., 2.

36 Ibid., Ch. 2.

37 Harvey Cox, "Afterword", in The Secular City Debate, ed. Daniel Callahan (New York: Macmillan, 1966), 180.

38 Torsten Kälvemark, "Storstadens teologi”, Svensk pastoraltidskrift 8, no. 51-52 (1966).

39 Olle Engström, "Radikal kyrkokritik", Kristet Forum, no. 8 (1965).

40 Kerstin Anér, "Varen nyktra och vaken!" Vår lösen 57, no. 3 (1966).

41 Dagens Nyheter, 28 April 1966. Regarding the programme Tidsspegel, see Dag Nordmark, Finrummet och lekstugan: Kultur- och underhålningsprogram $i$ svensk radio och TV (Stockholm: Prisma, 1999), 112-117.

42 Anér,"Varen nyktra och vaken!" 167.

43 Småorter och tätorter (Stockholm: Statistiska Centralbyrån, 2009), 83, 87.

44 Kälvemark, "Storstadens teologi"; Bernt Eklundh, "Den frigörande storstaden: Tankar av en inkorporerad", Göteborgs-Tidningen, 6 January 1967; Bernt Jonsson, "Storstaden som religiöst problem", Aftonbladet, 11 January 1967.

45 See, for instance, Ralph Hjelm, "God Is Dead Theology", in The Encyclopedia of Christianity, vol. 2, E-I, eds. Erwin Fahlbusch and Geoffrey W. Bromiley (Grand Rapids: Eerdmans, 2001).

46 Lena Lennerhed, Frihet att njuta: Sexualdebatten i Sverige på 1960-talet (Stockholm: Norstedts, 1994), 222-223; Johan Sundeen, 68-kyrkan: Svensk kristen vänsters möten med marxismen 1965-1989 (Stockholm: Bladh by Bladh, 2017), 94-95.

47 Ingmar Brohed, Sveriges kyrkohistoria: 8. Religionsfrihetens och ekumenikens tid (Stockholm: Verbum, 2005), 45-46, 224.

48 See ad on page 10 in Vår kyrka no. 50, 1966.

49 For instance, there are identical ads in Svenska Dagbladet and Dagens Nyheter on 2 December 1966.

50 In his book about the "church of 68", historian of ideas Johan Sundeen mentions Kristet Forum and Varr lösen, together with the previously mentioned Var Kyrka, as important for the political turn to the left in Swedish Christianity around 1968. Sundeen, 68-kyrkan, 13.

51 Amythos, "Amerikansk revolutionsteologi”, Nya Väktaren 60, no. 4 (1967): 55. Amythos was the pseudonym of the journal's editor Axel B. Svensson.

52 Sven-Olov Wallenstein, "1966: Thinking the City", in A Cultural History of the AvantGarde in the Nordic Countries 1950-1975, eds. Tania Ørum and Jesper Olsson (Leiden: Brill, 2016).

53 Claes Caldenby, "The Time of the Large Programmes 1960-1975", in 20th-Century Architecture: Sweden, eds. Claes Caldenby, Jöran Lindvall, and Wilfried Wang (Munich: Prestel, 1998), 144.

54 Eva Rudberg, "Building the Welfare of the Folkhemmet 1940-1960", in 20th-Century Architecture: Sweden, eds. Claes Caldenby, Jöran Lindvall, and Wilfried Wang (Munich: Prestel, 1998), 136-137; Caldenby,"The Time of”, 152-154. 
55 Kristen demokratisk samling, Kristen demokratisk samling - en presentation (Stockholm: KDS, 1964), 6.

56 Johansson, Kristen demokrati, 122-125.

57 Eklundh, "Den frigörande storstaden"; Rune Pär Olofsson, "Halleluja, stad!" Expressen, 6 February 1967.

58 Anér, "Varen nyktra och vaken!"

59 Eric J. Sharpe, “Är storstaden Guds rike?” Vår lösen 58, no. 1 (1967). See also Kälvemark, "Storstadens teologi".

60 Ragnar Oldberg, "Vår herres suppleanter”, Kristet Forum, no. 6 (1966).

61 Larsson Heidenblad, "From Content to Circulation".

62 Cox, "Introduction", 1.

63 Lennerhed, Frihet att njuta. On the debate in Christian circles, see specifically pages 212-224.

64 Brohed, Sveriges kyrkohistoria, 255-266.

65 Engström, "Radikal kyrkokritik".

66 "Explosiv frikyrklig debatt om sekulariserat evangelium", Svenska Dagbladet, 29 December 1966; "Frikyrklig studentdebatt kring 'anonyma' insatser", Svenska Dagbladet, 3 January 1967.

67 Olofsson, "Halleluja, stad!" 4.

68 Krister Stendahl, “Teologi till vänster”, Vår lösen 57, no. 3 (1966): 132.

69 The ad was posted in Expressen on 23 August 1967. Interview and Ström's response: Per Ahlmark, "Statskyrkan passar inte någonstans i världen”, Expressen, 13 August 1967; Ingmar Ström, "Kyrkan enligt Stendahl”, Expressen, 17 August 1967. The week after the interview, there were responses and comments in both Expressen and the other large daily newspapers.

70 See, for instance, Bernt Eklundh, "Förargelsens präst: Rune Pär Olofsson”, GöteborgsTidningen, 20 April 1967; Olov Hartman, "En teologkavalkad, presenterad av Olov Hartman, om barnatro och sekularisering", Aftonbladet, 2 September 1971.

71 Per-Olof Hanson, "Hej stad?" Kristet Forum, no. 6 (1966): 195; Anér, "Varen nyktra och vaken!" 167.

72 Kälvemark, "Storstadens teologi”, 993. See also Oldberg, "Vår herres suppleanter”, 193; Sharpe, "Är storstaden Guds rike?” 55.

73 Engström, "Radikal kyrkokritik”, 274. See also Leif Åslund, “Teologi för teknopolis”, Arsbok för kristen humanism 28 (1966): 167.

74 David Holm, "Modern amerikansk teologi - några motiv", Årsbok för kristen humanism 28 (1966): 20.

75 David Holm and Harvey Cox, Tro i teknopol: studieplan till Harvey Cox: Har Gud skapat tätorten? (Stockholm: Studiebokförlaget/SKDB, 1967).

76 Ibid., 5.

77 The exception is Chapter 4, where Cox "travels around the world" and paints pictures of contemporary city life in New Delhi, Prague, Rome, and Boston.

78 Ibid., 22-23, 46-47.

79 Ibid., 16, 36.

80 Sharpe, “Är storstaden Guds rike?”; Gösta Wrede, “Historiesynen hos Einar Billing och Harvey Cox", Årsbok för kristen humanism 30 (1968).

81 Per Erik Persson, Att tolka Gud i dag: Debattlinjer i aktuell teologi (Lund: Gleerup, 1971), 40-42, 147-149.

82 For more on the institute, see Göran Gustafsson, Religionssociologiska institutets publikationer: forskningsrapporter, litteraturöversikter, analyserande artiklar, siffersammanställningar (Lund: Lunds universitet, 2013).

83 Berndt Gustafsson, Religion och samhälle: Introduktion till religionssociologien (Lund: Gleerup, 1972), 73. Two sociologists he does refer to in his discussions are Henri Desroche and Howard Becker.

84 Sundeen, 68-kyrkan, 114-115. 
85 Jarl Hemberg and Anders Jeffner, De valde ståndpunkt: Moderna texter om livsåskådning och moral (Stockholm: Verbum, 1968), 76-79. At about the same time as this book was compiled, early 1968, a text by Cox on the Christian-Marxist dialogue was translated and published in the Christian cultural journal Vår Lösen. Harvey Cox, "Nästa steg i dialogen kristna-marxister”, Vår lösen 59, no. 4 (1968).

86 Östling and Larsson Heidenblad, "Cirkulation”, 283.

87 Ibid.

88 McLeod, Secularisation, 2-3.

89 On reception and circulation as well as the circulation of a specific work, see Östling and Larsson Heidenblad, "Cirkulation", 280; Larsson Heidenblad, "From Content to Circulation".

90 Östling and Larsson Heidenblad, “Cirkulation”, 280. 